\title{
GENDERED URBAN SPACES AND STRANGENESS IN JEAN RHYS' GOOD MORNING, MIDNIGHT (1939)
}

\author{
Carla Martínez del Barrio, University of Oviedo, Spain \\ Email: martinezbcarla@uniovi.es
}

Received: June 3, 2021

Accepted: Septembre 15, 2021

\begin{abstract}
This article analyses Jean Rhys' 1939 novel Good Morning, Midnight from the standpoint of spatial and gender theory. Firstly, it explores the portrayal of gendered spaces in the modern city. In order to do so, it examines how Sasha Jensen challenges spatial constraints but is then identified as a stranger to the social order. Secondly, a parallelism between the urban automatisation of production and the female body is established to explore how consumer culture affects Sasha. Finally, it examines how the influence that Sasha's fractured subjectivity has on her social encounters, which situate her on a liminal space.

Keywords: Jean Rhys, Gender, Space, City, Stranger.

Resumen: Este artículo analiza la novela de Jean Rhys, Good Morning, Midnight (1939), desde teorías espaciales y de género. Primero, se explora la representación de los espacios de género en la ciudad moderna. Así, se examina cómo Sasha Jensen desafía las limitaciones espaciales y es identificada como una extraña en el orden social. En segundo lugar, se establece un paralelismo entre la automatización urbana de la producción y el cuerpo femenino para explorar cómo la cultura de consumo afecta a Sasha. Finalmente, se examina cómo la subjetividad fracturada de Sasha influye en sus encuentros sociales, situándola en un espacio liminal.
\end{abstract}

Palabras clave: Jean Rhys, Género, Espacio, Ciudad, Extraña.

\section{INTRODUCTION: CONCEPTUALISING GENDERED URBAN SPACES}

Gillian Rose defines space as "a fantasy of something all enveloping, something everywhere, unavoidable, unfailingly supportive" (1996: 62). Rose claims that space is a projection of our desire for an imagined reality that resembles real life. As such, space surrounds us and supports our conceptions of that reality: "space is the medium through which the imaginary relation between self and the Other is performed" (Rose 1996: 63). Although not equivalent terms, space and place are connected in the sense that spaces are conceptualisations or abstractions of places. If space is where imaginary relations are 
performed there will be as many spaces as interactions exist. Thus, new spaces are created when the same place is experienced differently. Along the same lines, Edward Soja's study on 'The Third Space' analyses the processes of socialisation that give space meaning and create different experiences of the same reality (1996: 29). From a gender perspective, Fran Tonkiss contends that "women's fear is spatialised", and their "perceptions of danger have a specific geography" (2005: 103). These gendered maps, which are based on ideas of personal safety, are simultaneously dependent on how one views space in relational terms (Mort 2000: 307). The associations between the self and the Other alter when the space where they are performed changes. It can be argued then that the characteristics of space are defined by and consequently depend on the link between the self and the Other. Whether looked at from a gender perspective or otherwise, space and identity co-exist in a symbiotic bond.

In this vein, a parallelism can be established between the relations of space and place and that of gender and sex. According to Linda McDowell and Joanne Sharpe, gender refers to "socially created distinctions between femininity and masculinity" (1997: 20). This implies that gender has many nuances and operates in a very large spectrum, with femininity at one side, a very broad middle ground, and masculinity at the other end. Like space, it is a concept that defines and is defined by social interactions. 'Sex', on the other hand, is relatively less complex in terms of definition and refers to difference as well, but biological -between men and women. Therefore, we can link space, gender and imagined reality and consider them in opposition to place, sex and reality. Tonkiss claims that gender is not defined by the limits of biology, but by social ties which shape and are shaped by space (2005: 94). Seeing that space is constructed by social interactions, which determine gender differences and are also shaped by space, we can consequently establish a significant correlation between the two. As Don Mitchell contends, "gender is spatially constructed in that it is constructed in and through particular social spaces (however defined)" (2000: 219). As a consequence, gender is always a social construction and so, if social spaces and relations vary, so will gender and its implications.

The significant relationship between gender and urban space, which is the main focus of this article, is amply portrayed by Jean Rhys in Good Morning, Midnight. The novel is set in 1930s Paris during Sasha Jensen's vacation and includes her memories of the period after the First World War, a time when she was also staying in Paris, got divorced and lost a newborn baby. "I have no pride -no pride, no name, no face, no country. I don't belong anywhere" (Rhys 2000: 38), says Sasha. She is English, but her family has disowned her, and she feels no sentiments towards her country of birth (she is English but does not define herself as such); her name is Sophia, but she has changed it to Sasha; she constantly changes her appearance; and feels scorned by people. She does not have a face, in a metaphorical sense, because she always wears a mask, that is, pretends to be a different person to hide behind the protection offered by the lie. Because she has no pride, no name, no face, no country and does not belong anywhere, she exists in a liminal space. As Victor Turner (1967: 86) would argue, she exists in a middle ground, rejected by one side -her family in London-, and not welcomed by the other-her acquaintances in Paris. Her return to the city in 1937 is framed in the interwar period which coincides with a world economic crisis and, as Britzolakis contends, illustrates the climate of imminent catastrophe in Europe leading to 
the Second World War $(2007,458)$. However, during this time Paris also represented a beacon of light for culture and progress and had a great affluence of migrants who helped create heterogeneous communities (Cortés 2013: 96) and when women, like Sasha, entered the job market. As Liz Bondi and Hazel Christie state (2000: 295), "the post-war period has been characterised by a marked increase in the participation of women in paid employment". The rise in female participation in the labour market points at a more progressive and egalitarian society, which is one of the main reasons why this period brought by great social changes for women in society. After the war, according to Wirth-Nasher (2015: 857), the boundaries between public and private spaces become more blurred because the home or the private is equated to the country which has been or is in danger of being invaded by a stranger. This may be the reason why Sasha regards space as if it were a battlefield and repeatedly uses warlike terms to describe it, such as "they can't kill you, can they?", "today I have left my armour at home" (Rhys 2000: 42) and "those voices that they brandish like weapons" (2000: 44). Indeed, following Tonkiss' argument (2005: 103), it can be contended that her perceptions of danger have a specific geography and that Sasha is further marked by the war and her condition as a stranger, which, as Elizabeth Grosz would explain (1992: 299), is already a liminal space in itself.

This article analyses the relationship between urban spaces and gender in Jean Rhys' Good Morning, Midnight. First, the character of Sasha is analysed in relation to the most relevant urban archetypes in the modern city: the flaneur and its female counterpart the flaneuse, and the stranger. Then, the article focuses on the analysis of gendered spaces in the modern city and the city itself in terms of gender: the city's dual nature, the male-female dichotomy in a patriarchal society, the concept of 'public woman' and the differences and similarities of public and private spaces and alternative views on them. Finally, it develops ideas on urban consumer culture and its effects on Sasha, by commenting on the 'male gaze', liminality, fractured subjectivities, and the automatisation of production and the female body.

\section{THE ART OF FLÂNERIE AND THE FIGURE OF THE STRANGER}

The term flâneur is a $19^{\text {th }}$ century literary type, associated with the modern European city, most notably with the city of Paris, and the writings of authors such as Charles Baudelaire or Honoré de Balzac. Flânerie is a recurrent research topic in the $20^{\text {th }}$ century, including Walter Benjamin as leading exponent in this line of literary analysis. A flaneur is a man of leisure, an explorer and observer, the dandy, an idler, a stroller fascinated by society but detached from it, whose home is the city. The flaneur is the modern hero, observing and being observed but never interacting with others (Baudelaire 1964, Benjamin 2002). The concept of the flaneur represents an androcentric account of modernity and urban spatial divisions based on gender differences, which assumes male supremacy over the city. As the observer, the flâneur constructs himself as the self. Through his gaze, women are subjected to him and othered. As such, this concept was created by, refers to and is embodied by men.

In the $19^{\text {th }}$ century and early $20^{\text {th }}$ century, the urban archetypes reserved for women were either the prostitute or whore and the exploited and passive working-class woman. The Victorian 'Angel in the House' was the female archetype associated with the domestic suburban realm, but not with the city. According to Tonkiss, the flâneur and the prostitute, 
as two urban archetypes, have a counter-opposed agency: the flaneur is the consuming and desiring subject, associated with detachment and distraction; whereas the prostitute is the troubling and consumed object, identified with involvement and infection (2005: 100). Feminist scholars concerned with urban gender geography (Wilson 2001, McDowell 1999) developed the flâneur's female counterpart: the flâneuse. In opposition to flâneur, the term flaneuse offers a feminist alternative to the highly privileged male figure by representing women who actively sought economic independence, sexual satisfaction and gender experimentation. However, it is worth noting that, compared to male flanerie, female flânerie is an even more exceptional phenomenon. The art of flanerie, due to its characteristics, requires a certain degree of economic opulence and independence, as well as a careless attitude, which was not the standard of living among $19^{\text {th }}$ and early $20^{\text {th }}$ century women because they faced a series of socio-spatial restrictions in the city. Indeed, the very first premise of flanerism is the freedom to move around the city, which makes this urban archetype an unlikely one for women and their conditioned spatial geography.

However, some could argue that Sasha Jensen has the very first condition needed for flânerism: she is in a big modern city, concretely the city of Paris, thought by Baudelaire to be the pinnacle of the art of flanerie (1964: 9-12). She also complies with the second condition because she can hardly ever be found indoors. Yet, Rhys complicates her characterisation as a flâneuse in several ways. Firstly, Sasha does not aimlessly walk around the city, because she purposely plans every move she makes. In fact, she has no spatial freedom because she is not welcomed in certain spots around Paris. Therefore, she is not an explorer, nor does she desire to explore the unknown as she always plays it safe, going to the places she knows will welcome her and avoiding the ones which will not. Secondly, she does not want to observe society because she is not fascinated by it at all. To her, humanity is a pack of damned hyenas (Rhys 2000: 144) and wolves whom you need to hide from (2000: 3 ). She feels used, scorned and ostracised (2000: 49) and, as such, she has no empathy for nor is attracted by society in any way. Moreover, theorists place a greater emphasis on how a flâneuse actively seeks economic and sexual independence. Regarding this matter, Sasha has depended on someone else's money all her life. When she moves to Paris with her husband, Enno, right after the First World War, her father stops financing her, so now she depends on what Enno can earn. Because her husband fails to do so, she earns some extra money working for a very wealthy lady writing stories for her (2000: 139). In this regard, Sasha, out of necessity, starts becoming more and more financially independent but to Enno's disapproval -even when she provides for both. Thus, even if she is independent, she does not enjoy it and feels ashamed. When her husband leaves her and her baby dies, she gets "in the habit of walking with the head down" (2000: 72) and she spends her days "plunged in a dream" (2000: 75). She does not observe the city and does not rejoice in the exciting possibilities it may offer, like an archetypical flâneuse would do. Instead she tries to blend in and go by unnoticed. As a consequence, it can be argued that Sasha Jensen cannot be considered a flaneuse because of the gendered routes she follows to stay safe around the city.

Alternatively, another more useful urban archetype to define Sasha is the stranger, which encompasses what is "out of place" but is at the same time familiar in the sense that its presence is acknowledged (Ahmed 2013: 20). The stranger lives in a liminal space, neither here nor there, both near and far. This literary figure grew in popularity during the 
$20^{\text {th }}$ century's urban massification provoked by the great affluence of peoples of different nationalities, ethnicities, religions and genders that were new to the city, either due to migration or in the case of most women, due to spatial changes brought by the social climate of the era. This figure represents a different subjectivity recognised as 'the Other' by the already present subjects. A stranger is not merely someone we have not encountered before or someone we do not know, but someone we have seen before and recognised as different from us (Ahmed 2013: 20). These encounters progressively create and shape in people's minds presupposed ideas, stereotypes and mental schemas on the stranger, who is seen as a dangerous threat to the space controlled by those who are in the position to other. Indeed, the urban archetype that fits in better with Sasha's condition as an outcast is the stranger. The stranger lives in an interstitial space, which Sasha occupies as an English woman in 1930s Paris without family (Rhys 2000: 36-37), husband (107), children (52) or friends (131), without a job and without money $(28,72)$, but with a shopping $(40,52,121)$ and drinking problem $(37,89)$ and a constant desire to change her outer appearance $(53)$. Sasha is recognised repeatedly as a stranger: in the hotel she stays in, in the cafés she goes to, in the park, in clothing stores, at restaurants. Everywhere around the city she is leered at and othered (2000: 28). She tries to navigate the city avoiding the places where she feels othered, but everywhere her condition as "the stranger, the alien, the old one" remains in every space she occupies (2000: 46).

\section{SASHA'S INTERSTITIAL URBAN SPACES}

According to Grosz, "the city orderly links and organises otherwise unrelated bodies" (1992: 298). Urban spaces represent society at large because people of all conditions, those "unrelated bodies", who otherwise and because of their differences would not find themselves living in the same place, co-exist in the city. Through this amalgamation, the city becomes a liminal or interstitial space, "a midway between the village and the state" (Grosz 1992: 299). It simultaneously shares the social ties that would exist in a rural space and the concerns of the state. This means that the city brings together a series of diverse social activities, processes and relations, as well as economic flows, power networks and political forms of organisation. Tim Edensor sees the city as "a place of comings and goings" with a dual nature, as it allows for the possibility of multiple connections, freedoms and pleasures, but at the same time it imposes spatial regulations, as is itself mapped, surveyed, colonised and possessed (2000: 214). For these reasons, the city and urban life constitute an interesting source for the analysis of gendered spaces.

The city can be considered as a contradictory space when analysing the possibilities it offers and the restrictions it imposes. As such, Sasha walks the streets of Paris, goes to cafés, bars, the cinema, parks and clothing stores but because she is mostly alone and unaccompanied she is regarded as a woman out of place, a stranger, a 'public woman' or a prostitute. Elizabeth Wilson studies this paradox from a gender perspective and states that "urban life is actually based on this perpetual struggle between rigid, routinised order, and pleasurable anarchy, the male-female dichotomy" (1991: 9). In this dichotomy, the male is associated with order, routine, regulations, institutions, the day and the public; while the female is aligned with chaos, pleasure, anarchy, the night and the private. The female 
associations are not inherently negative city-life aspects, but are undoubtedly relegated to the hidden margins. Women are systematically linked with these elements and stigmatised, in one way or another, at the same time. Wilson argues that "women have become an irruption in the city, a symptom of disorder, a problem: the Sphynx in the city" (1991: 9), they are "present in cities as temptresses, as fallen women, as lesbians but also as virtuous womanhood in danger, as heroic womanhood who triumphs over temptation and tribulation" (1991: 6). In the same vein, Maureen Flanagan and Maryann Gialanella see cities as "gender regimes that ideologically and concretely manifest a distinctive relationship among their political, economic and familial systems" (2011: 13). This regime is patriarchal because it mirrors discourses of power and privilege in which the behaviours of men are dimmed as normative and, as a result, urban structures, which, according to Bondi, are "generally viewed as the product of patriarchal gender relations" (1998: 177), are established following these male patterns to ensure and entitle male control and supremacy.

A woman challenging the male-female dichotomy, a woman like Sasha, existing on the liminality between two subjectivities ('good' and 'bad' woman) and not adhering to one, would be challenging the very same core that sustains capitalist patriarchal society itself, finding external and internal alienation as a result. Alienation, from others and from herself, is not an existential, inherent or natural characteristic but a specific historical consequence brought by the social polarisations or radicalisations about gender (Kegan 1983: 233). Sasha is a woman in public, the challenger of the male-female dichotomy and "a woman out of place" (Tonkiss 2005: 98) as the public sphere is thought to be no place for a moral respectable woman. Besides, a woman occupying a public space may be regarded as suspicious because her mere existence and placement are opposing the status quo, which determines they have no rightful place in public (Jordan 1990: 113). This suspicion may be reverted, according to Tonkiss (2005: 100), with male protection and legitimation. If Sasha is accompanied by a man, she is either legitimised or further stigmatised. This is exemplified by Sasha not feeling welcomed at any Parisian café unless she is accompanied by a man (Rhys 2000: 40) because, in that way, she does not feel out of place. Such behaviour is in line with Tonkiss' conceptualisation of spatial legitimisation, where a woman once presumed rightless to occupy a space, suddenly gains a right to it if accompanied by a man, which immediately changes her status and definition (2005: 100). As such, her definition will always be altered, either legitimised or stigmatised, by a male figure.

Sasha's relation to space shows the importance it has on her definition and position in society. The street outside the hotel Sasha stays in is described as "narrow, cobblestoned, going sharply uphill and ending in a flight of steps. What they call an impasse" (Rhys 2000: 9). The narrowness creates an impression of suffocation and the fact that it is made of stone implies coldness, an uninvited presence and a harsh welcoming. The street ends in an impasse, a dead end, a null point with no path ahead. It is described in a very pessimistic manner but still, Sasha spends most of her day -and night- outside. She navigates the geographies of fear, embodying the threat of the city streets at night. The "male gaze" (Mitchell 2000: 224) does not only participate in processes of female objectification, domestication and hypersexualisation but also in establishing a safe space for men, contrary to those found in a woman's geography of fear (Tonkiss 2005: 103). Here, class, nationality, ethnicity and gender are crucial elements of belonging and determine 
whether the city will welcome or scorn you. Sasha either feels out of place, insulted and rejected or sexualised, violated and objectified. The threat of violence, particularly sexual violence, finally materialises itself at the very end of the novel when the commis enters her hotel room and rapes her (Rhys 2000: 159).

Sasha's feelings are triggered by space: "This damned room -it's saturated with the past... It's all the rooms I've ever slept in, all the streets I've ever walked in" (Rhys 2000: 91). This passage exemplifies Sasha's connection to space: her emotions are triggered by space. This connection maker her anxious about the places she goes to and the people she encounters, never being fully comfortable nor trusting and always projecting self-doubt and past situations of rejection and violation onto new places. She negatively embodies new spaces due to her past experience elsewhere and is neither welcomed by the places themselves nor by the people that watch over them. Her presence as "Sphynx in the city" (Wilson 1991: 9), disrupts the social order. Sasha is the odd element, exiled from the protection of domestic spaces, she does not belong in the streets of Paris either, but still walks on them on a regular basis (2000: 39). Such behaviour challenges female domesticity as much as her lacking a home and staying in a hotel room instead. Sasha is leered at (2000: 28) because she is presumed to be a prostitute, -the troubling and consumed object -rather than a subject with autonomy, agency and spatial rights.

The novel shows a connection between Sasha and the city, where the street is personified and has agency: the "dark, powerful, magical" street defines and "knows" her (Rhys 1939: 89). According to Grosz (1992: 297), "the city is made and made over in the simulacrum of the body, and the body, in its turn, is transformed, 'citified,' urbanised as a distinctively metropolitan body". The city reflects the body and so, depending on Sasha's perspective, public urban space is described in an ambivalent way throughout the text: either as alluring, mystic, attractive, when Sasha is in danger and the city appears as full of possibilities rather than threats; or alienating and asphyxiating when she feels safe. Space is conditioned by her subjectivity, as Cohen (2000: 325) puts it, by "the immediate sensory spaces which our bodies navigate, the private mental spaces of our dreams, memories, and fantasies and the public geographical space that locates our journey within certain shared coordinates of social and cultural meaning". Half-way between dreaming and waking, senses and intuitions, fantasies and realities, we find interstitial urban spaces. Public and private spaces are conceptualised in contrast to each other: for instance, the shop Sasha works in (Rhys 2000: 16) or the street outside her hotel (2000: 9) would belong to the public sphere, whereas the houses she looks at while walking outside (2000: 28) would be part of the private sphere. However, between these, we find liminal spaces, neither public nor private; such as Sasha's hotel room (2000: 13), which exemplifies the urban confusion between the public and the private. As Walter Benjamin argues (2002: 406), in hotels, due to their liminal nature, "the street becomes room and the room becomes street". In the same vein, Daphne Spain contends that "public and private spheres are not separate worlds but aspects of the same sociocultural system" (1993: 139). As such, they reflect the same sociocultural structures and are not as opposed as they may seem. According to Arup Ratan (2016: 145), they are identified by the concept of liminality as sources of cultural transformation where new discursive forms, away from the rigid classification of space into public and private, may arise. 
Phil Cohen claims that private mental spaces are created in response to the necessity of moving away from public geographical space and its associations with social and cultural meaning, which may be unpleasurable to those who do not belong in said public space (2000: 329). Inventing a new individual mental narrative (e.g. dreaming, hoping or imagining) is a way of dealing with the logistics of urban life and saving these memories, dreams, hopes -or fears and anxieties-, from external judgement and exploitation. As such, Sasha either stays silent or, when she talks, she betrays her thoughts. In fact, the real Sasha only lives and communicates inside her head. Although her voicelessness can be considered negative, her mind can also be a safe space and a source of freedom: internally she can be whoever she wants to be and retreat inwards to escape from judgements and reprimands. Imagined mental spaces, considered by the self as real, are created as a coping mechanism in response to real spatial constrictions which reflect and are reflected by gender impositions. However, Sasha's coping mechanism creates a split in her subjectivity. On the one hand, there is who she is on the inside, and on the other, how she behaves in external space, either public, private or liminal. These splits, exemplified by the flashbacks Sasha experiences, create certain levels of self-degradation often prompted by numbing devices, through excess or default, which are cause and consequence of cultural items and consumer culture, such as Sasha's impulsive buying and excessive consumerism (Rhys 2000: 40, 53, 121).

\section{WOMEN, WORKSPACE AND URBAN CONSUMER CULTURE}

Through the so-called "male gaze", women are regarded as domestic and asexual objects except for such occasions when they are devised for male consumption; then, they are hypersexualised (Mitchell 2000: 224). Sasha is seen as domestic and asexual right after the First World War, when she was married. However, during her 1937 vacation, when she is single and goes out in public by herself, she is regarded as a 'public woman'. In spite of being opposite processes, in one way or another, Sasha in particular and women in general, are objectified. Female objectification may be realised through and sustained by cultural items, such as films, magazines or adverts, which are "powerful forums of displaying cultural ideas about gender" (Mitchell 2000: 220). Following Michel de Certeau's conceptualisation of the "practices of everyday life" (1984), Mitchell also stresses their importance because through them gendered ideas are followed or refused. Cultural items and the cultural industries by which they are manufactured reflect the society by which they are produced but also help to perpetuate those reflections further in time. Cohen claims that "the first rule of the capitalist city is the free circulation of commodities" (2000: 320). The capitalist city, as a system of social reproduction, needs gender distinctions, and gender needs the city to exist. In order for new cultural items to be sold -and fast, once spread by cultural industries-, new ideas on the possibility of gendered self-construction need to be internalised by society (Mitchell 2000: 222). Gender differences are charged with different social connotations that, as Young contends, the dominant use to other and classify the dominated in a "scale of bodies" (qtd. in Pérez 2009: 7), which measures the Others in opposition to the selves. As a consequence, Sasha's female body becomes a product of the city regulated by external impositions that dictate not only its appearance and movement around the urban. 
"Cultural industries", as Cohen puts it, "require and actively promote a dual labour market" (2000: 323). The shop Sasha worked at for three weeks is an example of Cohen's analysis (Rhys 2000: 16-26). The labour market is dual because high-class, skilled, rich, white and/or male workers can be found alongside working class, female, migrant, and/or racialised unexperienced workers. These co-existing urban groups also represent society at large, turning the city into a liminal representation of its higher and lowest spheres. Sasha works in a confined part of the store with no windows, while her boss' office, which is opened to the public and upstairs, is a symbol of his higher position in society (Rhys 2000: 16). As Spain argues (1993: 137), those differentiated physical arrangements reinforce spatial segregation based on gender differences. Sasha does not enjoy much agency and power in the workplace but she has time to think about her feelings and reflect on her environment: "I would feel as if I were drugged, sitting there, watching those damn dolls, thinking what a success they would have made of their lives if they had been women. Satin skin, silk hair, velvet eyes, sawdust heart-all complete" (Rhys 2000: 16). Her sarcastic comparison between the mannequins at the store and a 'perfect' woman hints at the unattainable conditions that are expected from women: a woman who gathers all the required gendered characteristics -eyes that do not see and a heart that does not feel- which dictate what women should and should not be. Mannequins, perfect on the exterior and dead on the interior, would fit the beauty canon established for women better than she would. Nevertheless, or precisely because she is aware of this unattainability, she exhibits child-like behaviour, crying in front of her boss and demonstrating she is emotionally unstable. Unlike the mannequins, she is a stranger and an alienated outcast.

Karl Marx introduces the idea that the modern city -and society at large- transformed the worker into an automatic motor of production, and then consumption, to ensure the durability of the city's perfect reproduction systems by imposing a fixed and unified subjectivity unto them (qtd. in Mitchell 2000: 221). During the 20th century, especially after the First and then, the Second World War, the city needed women to massively participate in the job market due to labour shortage and increase in demand. Women had already held jobs before this time, but the war and the new means of industrial production and mass consuming trends caused women like Sasha to barge in the employment market. This means that they are progressively accessing the public sphere, which as discussed before, was not perceived as theirs to occupy. In addition, women in the city enjoyed a greater degree of freedom. However, as Sasha's experience shows, restraints frequently come disguised as liberties. More social pressure was put on how women showed themselves in society: the clothes they wore, their make-up and their overall body image. In this period, more doors opened to women for experiencing transformations of their external, and consequently, internal selves. Yet, these doors, brought about more polarisations in the male-female dichotomy. Consequently, Sasha is a product perfected by every new hair colour and haircut she gets, every hat and dress she buys (Rhys 2000: 52-53). The promises of completeness and self-realisation that consumer society makes when promoting its products make her equate beauty with happiness, which will be achieved by consuming: "Just the sensation of spending, that's the point". (Rhys 2000: 121). Moreover, Sasha' spending on fashion represents not only a commodity of consumer capitalism but also a reason for women's longing, daydreams and fantasy (Joannou 2021: 464). She needs to recreate herself so that a different person stares back in the mirror. In order 
to do so, she needs to destroy any connection with her past self, she "must get on with this transformation act" (Rhys 2000: 53). The first step in that transformation was changing her name from Sophia to Sasha. Naming and especially re-naming are processes associated with imperialist discourses and used to claim ownership over something, someone or somewhere. Thus, she changes her name in an attempt to re-brand herself, take control over her own life and become a different person. However, she mentions her father still calls her Sophia, which foreshadows the impossibility of Sasha's transformative act (Rhys 2000: 36-37). Consequently, the unreachable mannequin perfection and the fact that she is treated as a stranger create a void and a sense of incompleteness -("I am empty of everything", Rhys 2000: 48)- which is filled by material things and superfluous experiences sold and promoted by society. The vicious circle of consumption never stops because her elation vanishes almost immediately after buying these goods. She is too alone, too poor, too old and too English for Paris, whereas Paris and its industries, stores, establishments, feed on her impossibility to fit in this society.

The automatisation and the massification of industrial production in the city have a direct impact on the concept of subjectivity. Grosz expresses her worries about the "cross-breeding of the body and machine" (1992: 303), a term that refers to the human characteristics taken by machines and the machine-like characteristics adopted by humans. Society is creating more human-like machines while downsizing humans into exact copies of one another, depriving them of any sense of self and individual emotional dimension and propriety. The city's emphasis on unifying identity creates automatons or automata that paradoxically, fighting unification, generate more diversification. As Zimmerman contends (2015: 81), Sasha considers herself a "bit of an automaton" (Rhys 2000: 10) in her obsession with gaining control over her disordered life. She plans where she will and will not go, what she will say, how she will feel and even the gestures that she will make, which she often copies from those around her, even if she is at the movies, where she laughs "heartily in the right places" (Rhys 2000: 15). She watches a character being happy, internalises that as what being happy feels and looks like and she reproduces it. Behaviour-wise she is more a machine than she is human. In association with Grosz' fear of society prompting humans to progressively have more machine-like characteristics (1992: 303), Sasha's attempts at accommodating to fit in are transforming her and her body into a product. She is a projection of the modern society she is a part of in that she makes herself appealing to others so that they accept her.

\section{CONCLUSION}

Jean Rhys' Good Morning, Midnight offers a portrayal of the city as a liminal and dual space, of spatial freedom and imposition, which allows us to establish a correlation between urban life and gender and study its subversion of the traditional spatial dichotomy male-female. This is complicated further by class and cultural hierarchies as represented, for instance, through the separation between Sasha and her boss in her job at the clothing store, which support and perpetuate already existing spatial segregation based on gender differences. Yet, as this article demonstrates, Rhys' novel also suggests how Sasha and other women's presence in public space opposes the status quo by means of their subversive spatial performances, such as going out at night and going to public places by herself or accompanied by unknown men or travelling abroad while being single. 
The traditional line between private and public spaces is often unclear in the text, prompting behaviours that take place in the 'wrong' sphere. This is depicted through Sasha's behaviour in public spaces, such as cafés and restaurants -when she cries on feeling outcasted-which creates a private space in a public place. In the same vein, the hotel room Sasha stays in exists as a liminal space, between the privacy of domesticity and the public exposure of the street.

Further, the capitalist city appears in the novel as feeding on women's fears about not fitting in society, creating physical insecurities in order to promote consumer culture. Sasha thinks her displacement and condition as a stranger will change if she adopts those practices. Instead, they only deviate her from the real problem, which lies at the core of the capitalist patriarchal society she lives in. Sasha embodies a 'stranger' in the city, recognised by her interstitial subjectivity which alienates and marginalises her. As the object of the dominant male gaze, she neither has a sense of privacy nor can return to the safety of a domestic space.

The importance of the focus on gendered spaces lies in how subtle spatial segregation is, which consequently fuels pre-existing gender differences. Although Rhys does not offer an optimistic perspective of space and its possibilities in the novel, when analysed in conjunction with gender theories from a contemporary point of view, spatial mutability offers hopeful possibilities for upgrading women's status in society because their mere presence challenges those who claim they do not belong in public urban space.

\section{REFERENCES}

Ahmed, S. 2013. Strange Encounters: Embodied Others in Post-Coloniality. London: Routledge.

Baudelaire, C. 1964 [1863]. The Painter of Modern Life. New York: Da Capo Press.

Benjamin, W. 2002. 1982. The Arcades Project. Trans. Ho. Eiland and K. McLaughlin. Cambridge: Harvard University Press.

Bondi, L. 1998. "Sexing the City". In Cities of Difference. Ruth Fincher and Jane M. Jacobs Eds. New York and London: Guilford. 77-201.

Bondi, L. \& Christie, H. 2000. "Working out the Urban: Gender Relations in the City". A Companion to the City. G. Brigde and S. Watson Eds. Hoboken, NJ: John Wiley \& Sons. 292-305.

BritzolaKis, C. 2007. "This Way to the Exhibition: Genealogies of Urban Spectacle in Jean Rhys' Interwar Fiction”. Textual Practice 21, 3: 457-482. http://yunus.hacettepe. edu.tr/ jason.ward/ied388novel3/britzolakisexhibitionrhys.pdf

CARrera, I. 2015. "The Stranger Flâneuse and the Aesthetics of Pedestrianism". Interventions: International Journal of Postcolonial Studies 17, 6: 853-865.

Cohen, P. 2000. "From the Other Side of the Tracks: Dual Cities, Third Space and the Urban Uncanny in Contemporary Discourses of Race and Class". A Companion to the City. G. Brigde and S. Watson Eds. Hoboken, NJ: John Wiley \& Sons. 316-330. 
Cortés, F. J. V. 2013. "Vagabunda y cautiva en París: paisaje urbano de la vulnerabilidad femenina en las novelas de entreguerras de Jean Rhys". Ángulo Recto 5, 2: 95-114. https://www.readcube.com/articles/10.5209\%2Frev_anre.2013.v5.n2.43333

De Certeau, M. 1984. The Practice of Everyday Life. Trans. S. Rendall. Berkeley: California University Press.

Edensor, T. 2000. "Moving through the City". In City Visions. D. Bell and A. Haddour Eds. City Visions. London: Routledge. 121-137

Flanagan, M. A. \& Valiulis, M. G. 2011. “Gender and the City”. Frontiers: A Journal of Women Studies 32, 1: 13-19.

Grosz, E. 1992. "Bodies-Cities". In Sexuality and Space. B. Colomina Ed. Princeton: Princeton Architectural. 297-303.

JoAnNOU, M. 2012. "All right, I'll do anything for good clothes": Jean Rhys and Fashion". Women: A Cultural Review 23, 4: 463-489.

JoRdan, J. 1990. "Black Feminism: the Politics of Articulation". In Identity: Community, Culture and Difference. J. Rutherford Ed. Interview by Pratibha Parmar. London: Lawrence and Wishart. 101-126.

Kegan, J. 1983. "Good Morning, Midnight; Good Night, Modernism”. Engagements: Postmodernism, Marxism, Politics 11, 1/2: 233-251.

Marx, K. 1887. Capital: A Critique of Political Econom. Vol 1. Trans. S. Moore and E. Aveling. Moscow: Progress.

McDowell, L. \& Sharpe, J. P. 1997. Space, Gender, Knowledge: Feminist Readings. London: Routledge.

McDowell, L. 1999. Gender, Identity, and Place: Understanding Feminist Geographies. Cambridge: Polity.

Mitchell, D. 2000. "Feminism and Cultural Change: Geographies of Gender". Cultural Geography: A Critical Introduction. Oxford: Blackwell. 199-229.

Mort, F. 2000. "The Sexual Geography of the City". In A Companion to the City. G. Brigde and S. Watson Eds. Hoboken, NJ: John Wiley \& Sons. 307-315.

PÉreZ, I. F. 2009. Espacio, Identidad y Género. Sevilla: Arcibel.

Ratan, A. 2016. "Liminality in Post-Colonial Theory: A Journey from Arnold van Gennep to Homi K. Bhabha”. An International Journal of Social Sciences 1, 1: 145- 153. https:// www.rnlkwc.ac.in/pdf/anudhyan/volume1/Liminality-in-Post-Colonial-Theory-AJourney-from-Arnold-van-Gennep-to-Homi-K-Bhabha-Arup-Ratan-Chakraborty.pdf

Rhys, J. 2000. Good Morning, Midnight. London: Penguin.

Rose, G. 1996. “As if the Mirrors Had Bled: Masculine Dwelling, Masculinist Theory and Feminist Masquerade". In Bodyspace: Destabilizing Geographies of Gender and Sexuality. N. Duncan Ed. New York: Routledge. 62-63. 
SojA, E. 1996. Thirdspace: Journeys to Los Angeles and Other Real-and-Imagined Places. Oxford: Blackwell Publishing.

SpaIN, D. 1993. “Gendered Spaces and Women's Status”. Sociological Theory 11, 2: 137-151.

Tonkiss, F. 2005. "Embodied Spaces: Gender, Sexuality and the City". In Space, The City and Social Theory. F. Tonkiss Ed. Cambridge: Polity. 94-112.

Turner, V. 1967. "Betwixt and Between: The Liminal Period in Rites de Passage". The Forest of Symbols. Ithaca: Cornell University Press. 93-112. http://hiebertglobalcenter. org/blog/wp-content/uploads/2013/03/Reading-20-Victor-Turner-Betwixt-andBetween.pdf

WiLson, E. 1991. The Sphinx in the City: Urban Life, the Control of Disorder, and Women. Berkeley: California.

Wilson, E. 2001. “The Invisible Flâneur". In The Contradictions of Culture: Cities, Culture, Women. E. Wilson Ed. London: Sage. 72-90.

Wirth-Nasher, H. 2001. “Impartial Maps: Reading and Writing Cities”. In The Handbook of Urban Studies. R. Paddison Ed. London: Sage. 52-66.

Young, I. 1990. "The Idea of Community and the Politics of Difference". Feminism/ Postmodernism Ed. Linda Nicholson. London: Routledge. 19-23.

Zimmerman, E. 2015. "Always the same stairs, always the same room: The Uncanny Architecture of Jean Rhys' Good Morning, Midnight". Journal of Modern Literature 38, 4: 74-92. https://core.ac.uk/download/pdf/76972847.pdf 